\title{
IMPACT OF PROBIOTICS ON STAPHYLOCOCCUS AUREUS GROWTH IN SOME DAIRY PRODUCTS
}

\author{
EL-KHOLY, A.M. ${ }^{1}$; HASSAN, G.M. ${ }^{2}$; SAMIA I. AFIFI ${ }^{3}$ and MOHAMED, E.A.S ${ }^{4}$ \\ ${ }^{1,2}$ Food Hygiene Department, Faculty of Veterinary Medicine, Beni-Suef University, Egypt. \\ ${ }_{3,4}$ Animal Health Research Institute, Beni-Suef Branch, Dokii, Egypt.
}

Received: 26 August 2018; Accepted: 24 September 2018

\begin{abstract}
A total of 180 samples of yoghurt (small and large scale), soft white cheese (Tallaga and Feta) and rayeb milk (small and large scale) 30 of each were arbitrarily collected from different localities as dairy shopes and markets in Beni-Suef city, Egypt. The results revealed that the mean values of S.aureus were $5.7 \times 10^{3} \pm 3.2 \times 10^{3}$, $9.3 \times 10^{2} \pm 3.9 \times 10^{2}, 4.3 \times 10^{4} \pm 2 \times 10^{4}, 5.1 \times 10^{3} \pm 1.7 \times 10^{3}, 3.6 \times 10^{4} \pm 1.3 \times 10^{4}$ and $5.5 \times 10^{2} \pm 2.7 \times 10^{2}$, respectively. Also, the result regarding that $60 \%$ of examined $S$. aureus strains were enterotoxigenic by multiplex PCR technique as carried one or two se- genes. The present work evaluated the influence of probiotic as live organisms on the survival of S.aureus in some dairy product as Tallaga cheese and rayeb milk during their production and refrigerator storage.
\end{abstract}

Key words: Yoghurt, Soft cheese, Rayeb milk, S.aureus, enterotoxigen, PCR, probiotic, L.acidophilus and B.bifidum.

\section{INTRODUCTION}

Milk and dairy products play an essential role in human nutrition therefore, it is preferred that $25 \%$ of the daily nutrition intake contains dairy products (Hoven, 1987).

Fermented milk precognitive as a dairy product obtained by the fermentation of milk through the action of Lactic Acid Bacteria "LAB" which resulted in lowering of $\mathrm{pH}$ with or without coagulation. These bacteria must be viable, active and abundant in the product. The popular fermented milk products are Yoghurt, Labneh, Acidophius milk, Rayeb and Butter milk, etc. (Ahmed et al., 2014).

Yoghurt is a classical fermented milk product which consumed all over the world mainly in northern European countries, Balkans, Middle- East and Indian sub-continents (Tamine, 2002).

Yoghurt is manufactured by the addition of healthy bacteria and live cultures to milk as Streptococcus thermophilus and Lactobacillus delbrueckii subsp. bulgaricus (Steinkraus, 1997 and Tamine and Robinson, 2007). The main reason pointed out for yoghurt and other fermented dairy products

Corresponding author: Dr. MOHAMED, E.A.S.

E-mail address: bataahmed_2011@yahoo.com

Present address: Animal Health Research Institute, Beni-Suef Branch, Dokii, Egypt.
(Guarner et al., 2005; McKinley, 2005; ÁlvarezLeón et al., 2006 and Cueva and Aryana, 2008).

consumption is the cultural, as improves lactose digestion and eliminates the symptoms of lactose intolerance, high in protein, calcium, phosphorus, magnesium, potassium, riboflavin and vitamin A Soft white cheese is processed from cow's or buffalo's milk or a mixture of them according to the Egyptian cheese-making technology. Production may be artisanal or industrial, depending on whether the cheeses are manufactured with raw thermized (heated below pasteurization level) or pasteurized milk (Robinson and Tamime, 2002).

Laban Rayeb is one of the fermented milks product consumed by different ages in Egypt and other countries, for its highly nutritive value and therapeutic properties (Sayed, 2012).

The genus Staphylococci includes over 30 species, with 18 of these species and subspecies are of potential hazard in food poisoning as they produce either coagulase, heat stable nuclease or enterotoxins. S. aureus subsp. aureus is coagulase positive and the most are common enterotoxigenic species (Le Loir et al., 2003 and Loncarevic et al., 2005). S. aureus is a common pathogen associated with serious community and hospital acquired diseases and has been considered for long as the important food- borne pathogen and made a major problem of public health (Pesavento et al., 2007 and Morandi et al., 2009). 
S. aureus is a desiccation tolerant organism as it has the ability to survive in dry and stressful environments and can grow in wide range of temperatures $\left(7^{\circ}\right.$ to $48.5^{\circ} \mathrm{C}$; optimum 30 to $37^{\circ} \mathrm{C}$ ), $\mathrm{pH}$ (4.2 to 9.3 ; optimum 7 to 7.5 ), and sodium chloride concentration up to $15 \% \mathrm{NaCl}$. It is existing on human nose, skin and inanimate surfaces such as clothing and surfaces (Chaibenjawong and Foster, 2011).

S. aureus produces 15 enterotoxins (Atichou et al., 2004). The five classical enterotoxins (SE, type A, B, C, D and E) which queried for $95 \%$ of staphylococcal food poisoning (SFP) cases and the new types of SEs (SEG-SEO) responsible for other cases (Jay et al., 2005).

SEs are highly resistant to environmental conditions such as heat, freezing and drying (Le Loir et al., 2003). They are also resistant to lowered $\mathrm{pH}$ and proteolytic enzymes such as pepsin or trypsin that rendering them completely functional in the gastrointestinal tract after ingestion. They also belong to superantigens family, which subverted the immune system of the host by targeting the innate and adaptive responses (Argudín et al., 2010).

The invention of a large number of $S$. aureus in the food $\left(>10^{6} \mathrm{cfu} / \mathrm{g}\right.$ or $\left.\mathrm{ml}\right)$ is verificated that the isolated $S$. aureus strain is able to produce the enterotoxin (Najera-Sanchez et al., 2003). Dairy products with a level of enterotoxin as low as $0.5 \mathrm{ng}$ $/ \mathrm{g}$ or $\mathrm{ml}$ are frequently involved in SFP cases (Bergdoll, 1991 and Vernozy-Rozand et al., 2004).

SFP symptoms as nausea, abdominal cramps, diarrhea and a characteristic projectile vomiting are appeared within 1-6 $\mathrm{h}$ from ingestion of contaminated food, depending on individual susceptibility and ingested toxic dose and the clinical signs disappear within 24-48 h. Deaths occur rarely and specifically in the very young or elderly (Jay et al., 2005).

A concentration of $10^{5}$ bacteria/g in foods is sufficient for toxin production and induction of disease (Kluytmans and Wertheim 2005, Paciorek et al., 2007 and Fooladi et al., 2010).

SEA and SEB consider the most FP agents (> 60\%) in USA and England (Kluytmans and Wertheim 2005). As associated with human contamination (mainly food manipulators) and SEC and SED are associated with animal contamination (mainly cows and pigs) (Un Lee et al.,1998).

Enterotoxins have been detected by various methods but the PCR technique has the ability of detecting specific gene sequences by DNA amplification (Mclauchlin et al., 2000; Mehrotra et al., 2000; Sharma et al., 2000 and Omoe et al., 2002). PCR is much faster and can be applied to detect SEs in most kinds of food such as milk and cheese products irrespective of the available conventional techniques (compared with animal tests) (Shijia et al., 2016).

New SEs (SEG, SEH, SEI and SEJ) and its genes were reported through the 1990s, (Zschock et al., 2005). More recent data resulting from partial or complete genome sequence analyses have led to the description of further "new" se genes: sek, sel, sem, sen, seo, sep, seq, ser and seu. (Omoe et al., 2002 and Letetre et al., 2003). The role of these new SEs has not yet been explained in FPcases (VernozyRozand et al., 2004 and Boerema et al., 2006).

Probiotics are known as live microorganisms that have alternative effect to antibiotics in the treatment of foodborne diseases as it provide a health benefit to the host when administered in adequate amounts. (FAO/WHO, 2001 and Sanders, 2003). It's important to analyze probiotics stability in their characteristics during manufacture and storage and to ensure that they are retained in different types of foods (Lee and Salminen, 1995 and Huis In't Veld and Shortt, 1996).

Probiotics have a public health significance against many diseases such as pathological allergic including atopic eczema and rhinitis, diarrhoea, necrotizing enterocolitis inflammatory bowel disease and viral infection (Robles Alonso and Guarner, 2013). Also they have benefit effect in lactose digestion, control intestinal infections and balance the intestinal mucosal barrier, immunogenic effects, shortening the duration of diarrhea and other health effects (Salminen et al., 1998 and Pal and Jadhav, 2013).

Dairy products consider as probiotic carrier foods especially fermented milk products (Bergamini et al., 2005). Lactobacillus and Bifidobacterium genera are the most known probiotic microorganisms (Prasad et al., 2000).

Lactobacilli and bifidobacteria are recognized as a good example for health-promoting constituents of the microflora. Lactobacilli has a health importance in gastrointestinal disturbance as reduce constipation, infantile diarrhea, traveller's diarrhea, irritable bowel syndrome (IBS), lactose-intolerant individuals and resist infections such as Salmonellae. Bifidobacteria also has benefit effect as stimulate the immune system, inhibit pathogen growth, help to restore the normal flora after antibiotic therapy, produce B vitamins, reduce blood ammonia and blood cholesterol levels (Gibson, 2002).

PH is an important factor which can dramatically affect bacterial growth, Lactobacillus spp. as a 
probiotic can tolerate a wide range of $\mathrm{pH}$ (1-9) and grow well at acidic $\mathrm{pH}$ 1-5 (Chowdhury et al., 2012).

Food containing such $\mathrm{LAB}$ should contain at least $10^{7}$ live microorganisms per $\mathrm{g}$ or $\mathrm{ml}$ at the time of consumption, in order to benefit the consumer (Ishibashi and Shimamura, 1993 and Hathout and Aly, 2010).

Probiotic bacteria possess antagonistic activity against numerous food-borne disease organisms such as S. aureus, Salmonella spp., E. coli, L. monocytogenes and $\mathrm{Cl}$. perfringens (Millette et al., 2007). Lactobacillus acidophilus consider as one of the body's primary defense mechanisms against Candida as it has protection effect against pathogenic yeast infections (Mercenier et al., 2003). As well as, many researches indicated that L. acidophilus is the most popular species of probiotic bacteria produces substances that slow or prevents the growth of Candida (Yang, 2000 and Mohamed et al., 2010).

Lactic acid bacteria have antagonistic effect due to producing some substances such as organic acids (lactic, acetic, propionic acids), carbon dioxide, hydrogen peroxide, diacetyl, low molecular weight antimicrobial substances and bacteriocins (Quwehand and Vesterlund, 2004).

Therefore, this study was planned on the impact of probiotics on S.aureus growth in some dairy products.

\section{MATERIALS AND METHODS}

I-1- Collection and handling of the samples:

A total of 180 samples of yoghurt (small and large scale), soft white cheese (Tallaga and Feta) and rayeb milk (small and large scale) 30 of each were arbitrarily collected from different localities as dairy shopes and markets in Beni-Suef city, Egypt. The collected samples were delivered as soon as possible to the laboratory in an insulated ice-box and examined in the same day.

I-2-a- Enumeration and isolation of Staphylococcus aureus.

It was performed on Baird parker agar plate according to APHA, (1992).

1-2-b- Identification of the isolated Staphylococcus organisms.

Microscopical and biochemical examination were done according to Quinn et al. (2002).

1-3- Detection of enterotoxins genes of Staphylococcus aureus.
Nine pairs of primers have specific sequence were supplied for detection five enterotoxins genes of S.aureus as Sea, Seb Sec Sed and See, according to Mehrotra et al. (2000).

1-4- Impact of probiotic bacteria on the growth and survival of Staphylococcus aureus in vitro:

\section{1-4-a- Bacterial strains:}

The bacterial strains used in this study were S.aureus which obtained from this work after the identification by multiplex PCR, Lactobacillus acidophilus and Bifidobacterium bifidum which were obtained from The Animal Health Research Institute (Dokii, Egypt).

1-4-b- Media used for growth of the bacteria:

Probiotic strains were propagated in de Man Rogosa and Sharpe (MRS) broth supplemented with $0.05 \%$ L-cysteine hydrochloride (Sigma, Buchs, Switzerland) at $37^{\circ} \mathrm{C}$ for $24 \mathrm{~h}$ under an atmosphere of $5 \% \mathrm{CO}_{2}$ for L. acidophilus and anaerobically for B.bifibum. S.aureus strain was propagated in $10 \mathrm{ml}$ of Brain-Heart Infusion broth (CM1135B, Oxoid) at $37^{\circ} \mathrm{C}$ for $24 \mathrm{~h}$.

\section{1-4-c- Suspension inoculations for bacterial} strains:

S.aureus counts were adjusted at concentration of $10^{8} \mathrm{cfu} / \mathrm{ml}$, while probiotic strains were adjusted at concentration of $10^{9} \mathrm{cfu} / \mathrm{ml}$.

\section{1-4-d- Tallaga cheese manufacturing:}

Cheese was prepared according to the method outlined by Abou-Donia (1986) as the sodium chloride was added at levels of $6 \% \mathrm{w} / \mathrm{v}$ and the samples were refrigerator storage and examined each two days.

\section{1-4-e- Rayeb-milk manufacturing:}

Rayeb-milk was prepared according to the method outlined by Sayed (2012) and Ramesh and Arun (2013) and the samples were refrigerator storage and examined each day.

\section{1-4-f-Chemical analysis of manufactured products:}

The $\mathrm{pH}$ of all cheese and rayeb samples was measured using (AD 111 digital $\mathrm{pH}$ meter 609) at $25 \pm 1{ }^{\circ} \mathrm{C}$ APHA (1974).

The salt percentage (sodium chloride content) in cheese samples was measured by the standered method described by APHA (1992).

1-4-g-Enumeration of probiotic strains was performed according to Souza and Saad (2009).

1-4-h- Enumeration of S.aureus was done according to Roberts and Greenwood (2003). 


\section{RESULT}

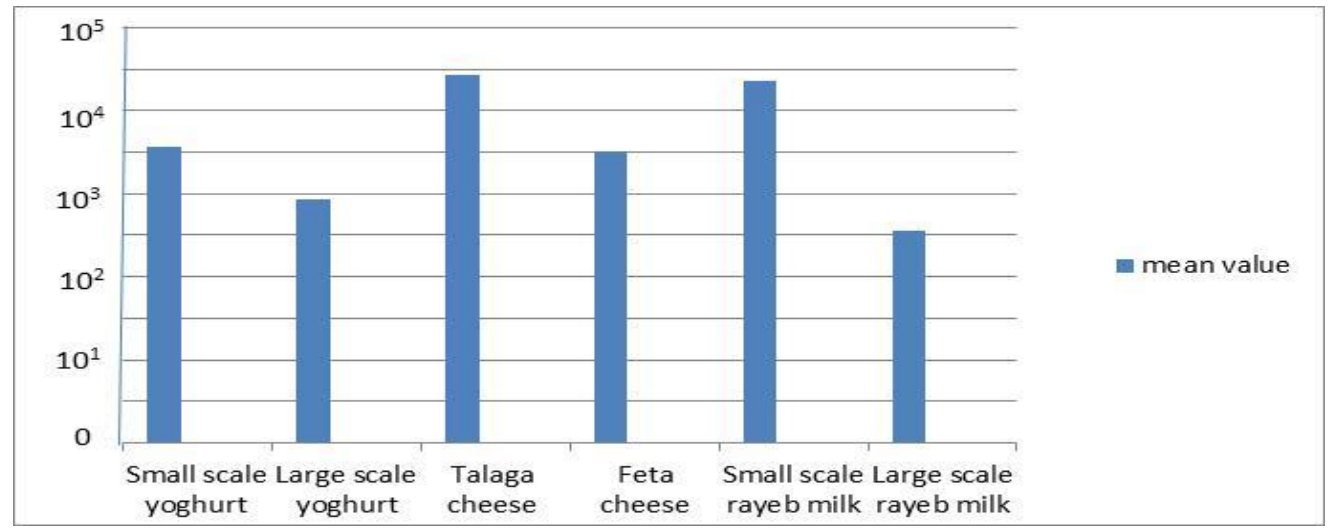

Figure 1: Statistical analytical results of the examined samples based on their S.aureus count $/ \mathrm{ml}$ or $\mathrm{g}$.

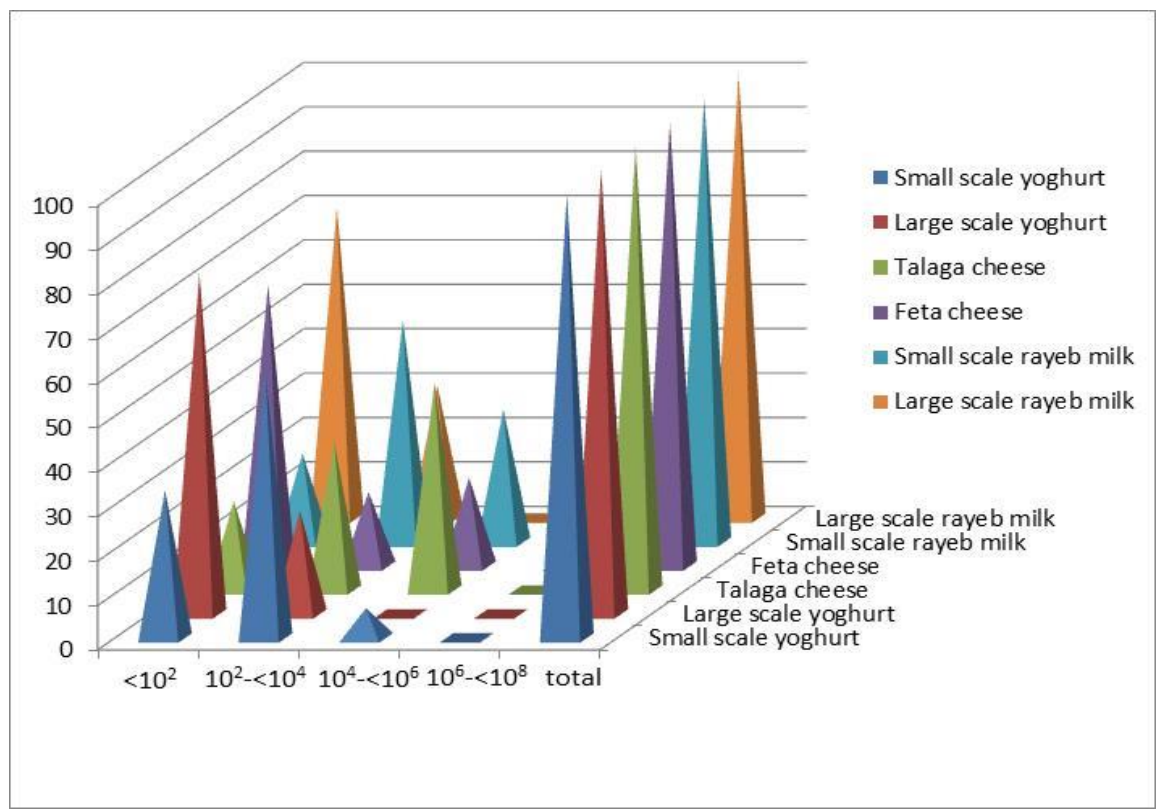

Figure 2: Frequency distribution of the examined samples based on their S.aureus count $/ \mathrm{ml}$ or $\mathrm{g}$.

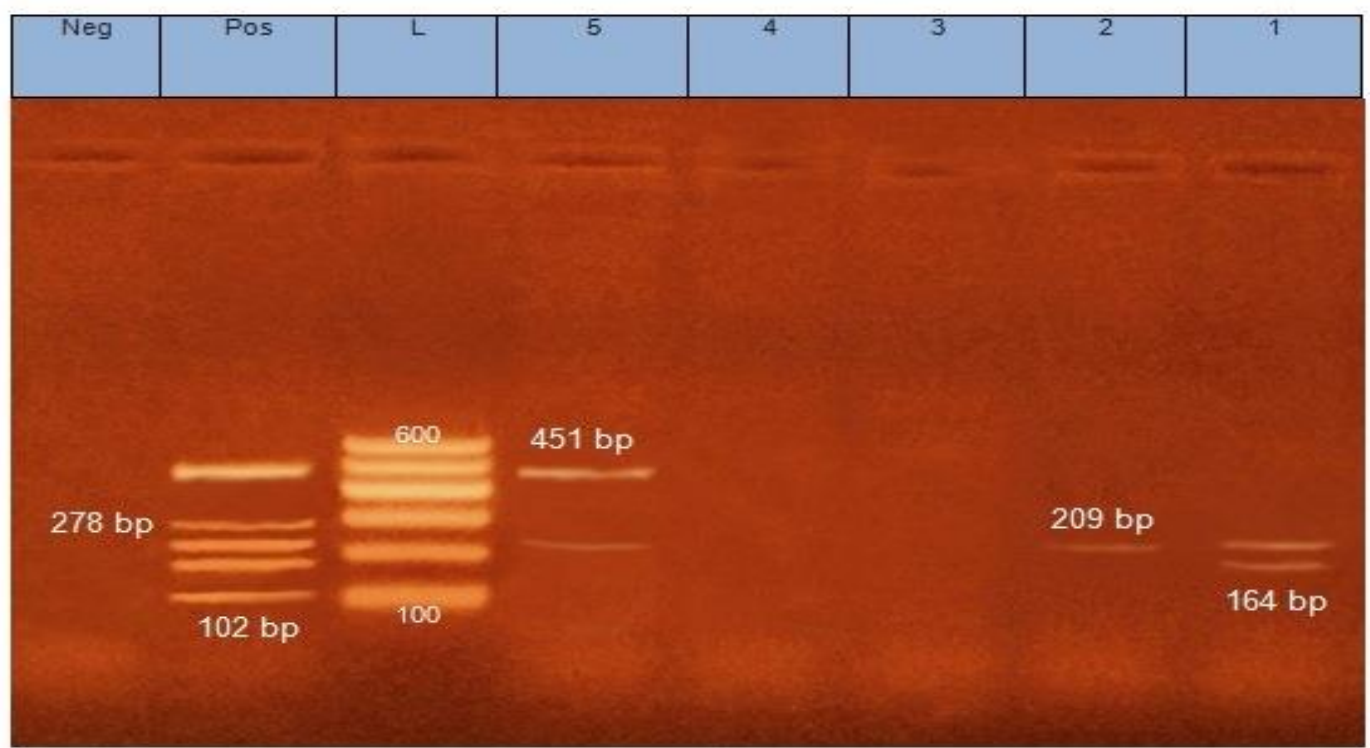

Figure 3: Incidence of enterotoxins genes of Staphylococcus aureus. 


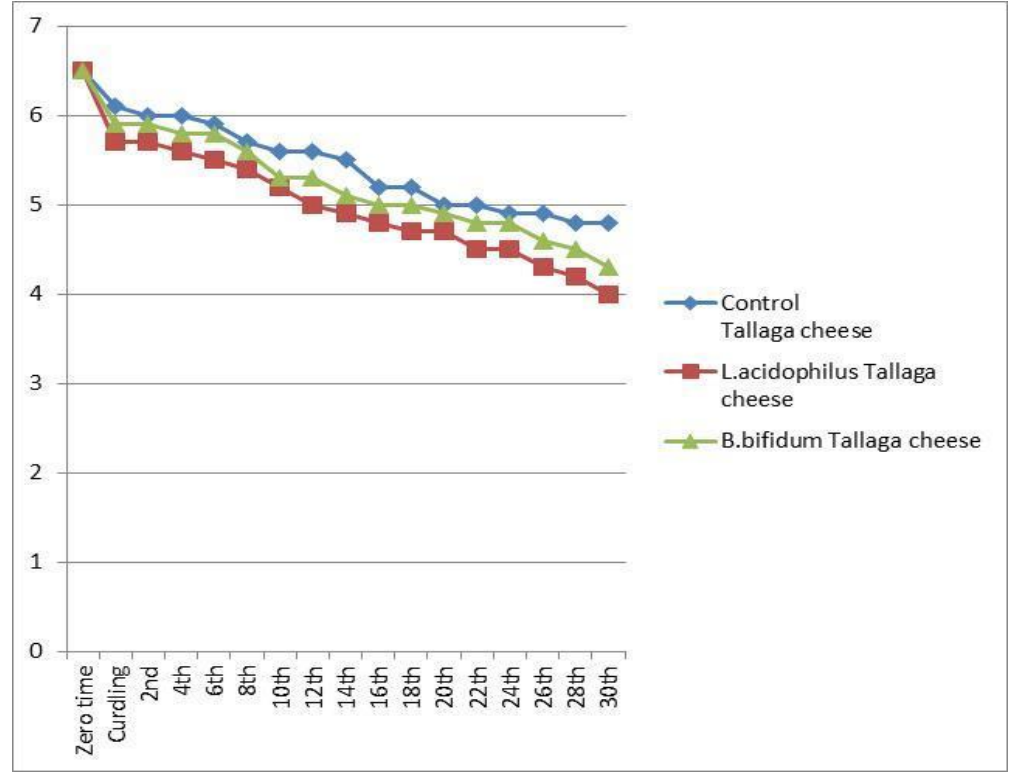

Figure 4: $\mathrm{pH}$ of control and probiotic Tallaga cheese during production and refrigerator storage.

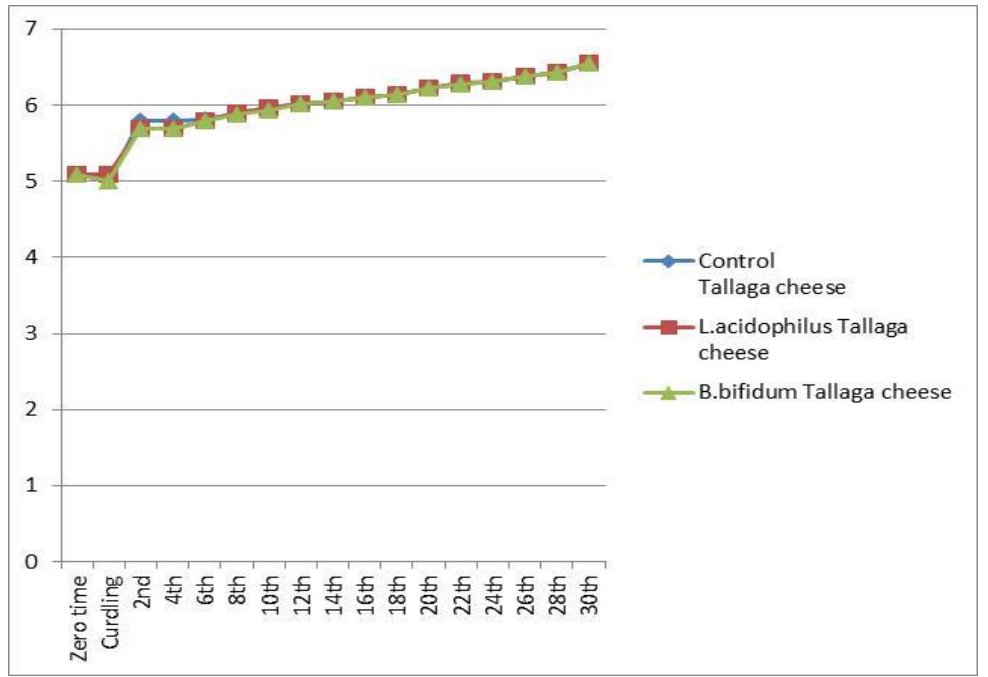

Figure 5: Salt content $(\mathrm{NaCl} \%)$ of control and probiotic Tallaga cheese during production and refrigerator storage.

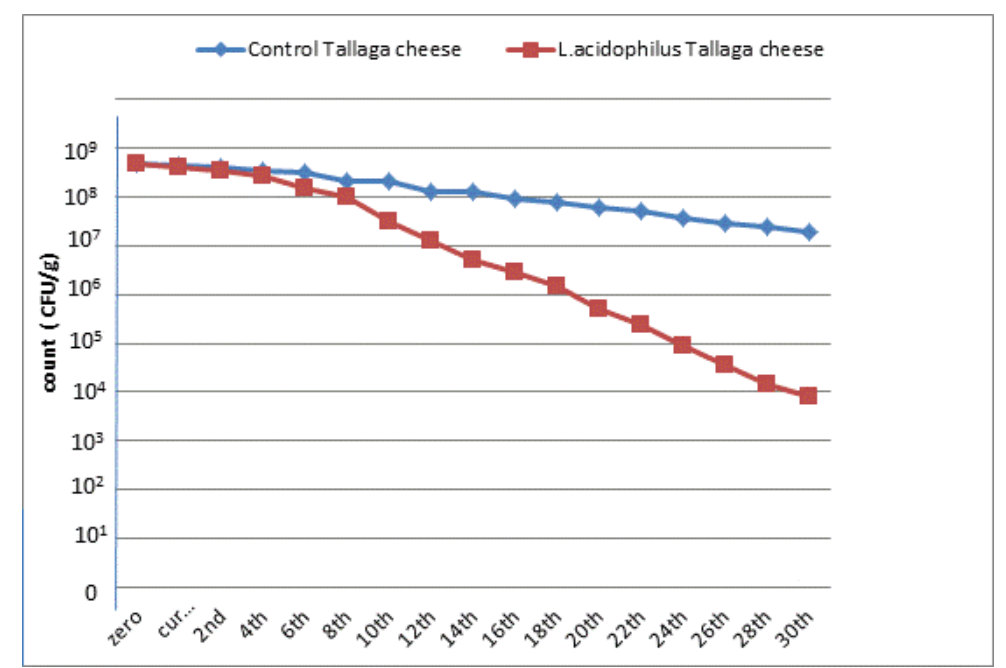

Figure 6: Impact of L.acidophilus on S.aureus organism in Tallaga cheese during production and refrigerator storage. 


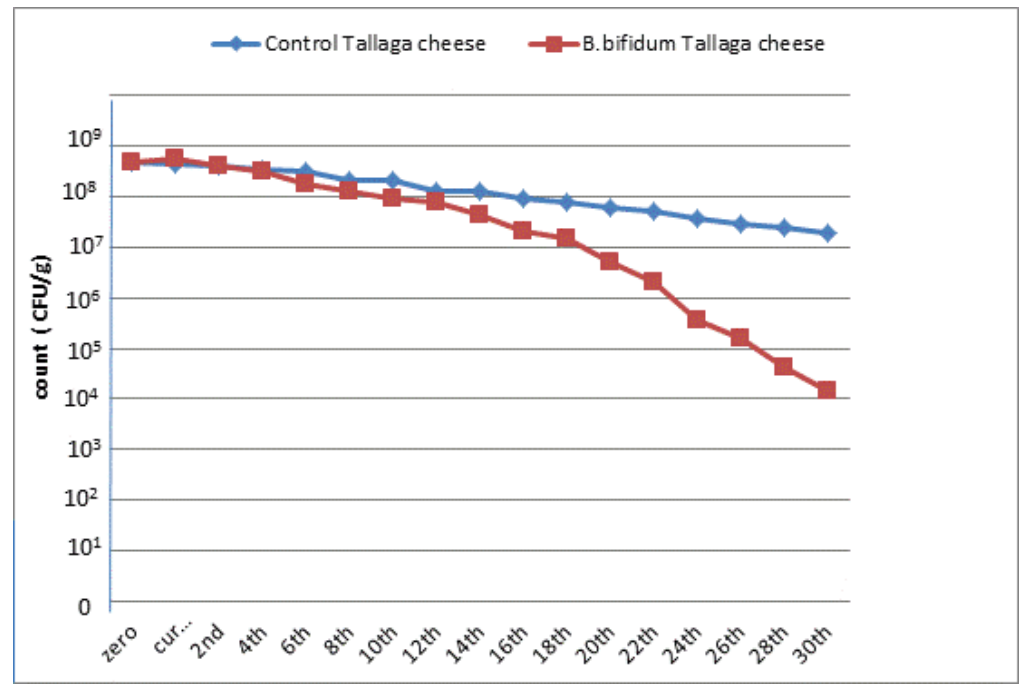

Figure 7: Impact of B.bifidum on S.aureus organism in Tallaga cheese during production and refrigerator storage.

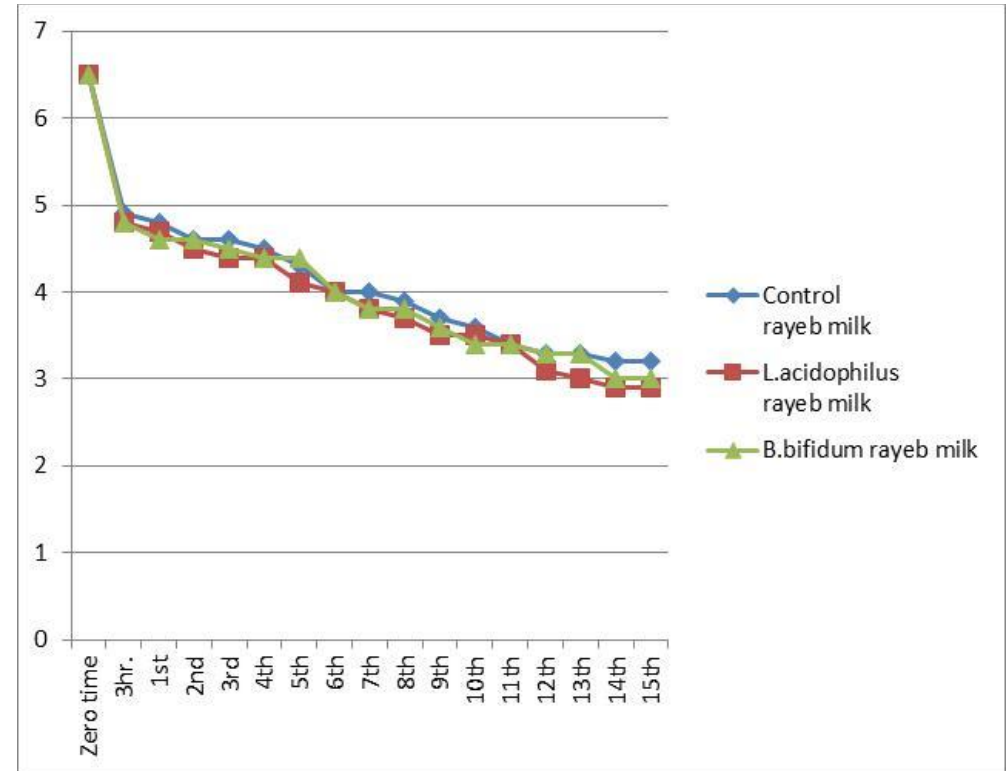

Figure 8: PH of control and probiotic rayeb milk during production.

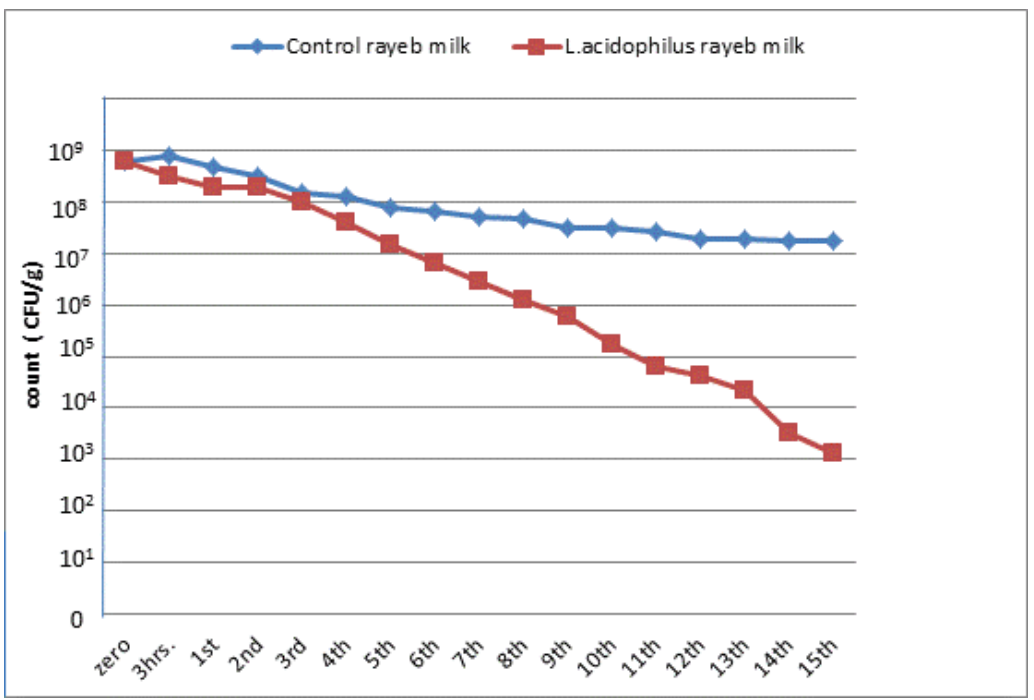

Figure 9: Impact of L.acidophilus on S.aureus count (growth) in rayeb milk during production and refrigerator storage. 


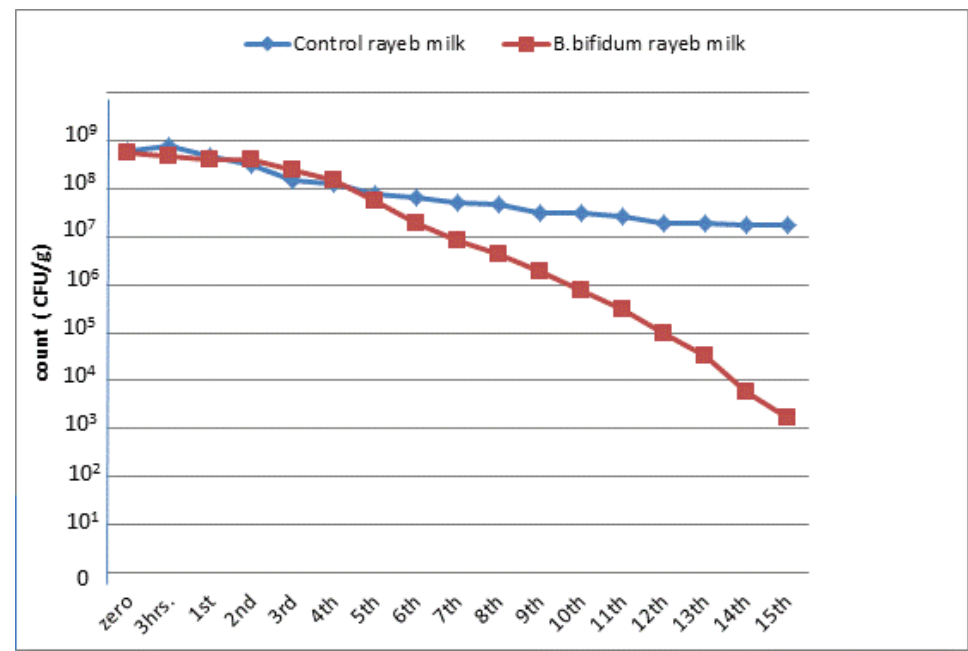

Figure 10: Impact of B.bifidum on S.aureus count (growth) in rayeb milk during production and refrigerator storage.

\section{DISCUSSION}

The high contamination rate of dairy products with S. aureus is mainly due to use of poor quality milk, environmental contamination as unclean hands of worker either suffering from diseased or apparent healthy carriers, unsanitary production and marketing practices (Araujo et al., 2002).

In this study, it is obvious in Figure (1) that the occurrence of S.aureus organism was 66.7, 23.3, 80, $36.7,80$ and $30 \%$ of the examined yoghurt (small and large scale), soft white cheese (Tallaga and Feta) and rayeb milk (small and large scale) samples with mean values of $5.7 \times 10^{3} \pm 3.2 \times 10^{3}, \quad 9.3 \times 10^{2} \pm$ $3.9 \times 10^{2}, \quad 4.3 \times 10^{4} \pm 2 \times 10^{4}, \quad 5.1 \times 10^{3} \pm 1.7 \times 10^{3}$, $3.6 \times 10^{4} \pm 1.3 \times 10^{4}$ and $5.5 \times 10^{2} \pm 2.7 \times 10^{2}, \mathrm{cfu} / \mathrm{ml}$ or g., respectively. The highest frequency distribution $60,76.7,80,63.3,50$ and $70 \%$ lies within the ranges of $10^{2}-<10^{4},<10^{2}, 10^{2}-<10^{6},<10^{2}, 10^{2}-<10^{4}$ and $<10^{2}$, respectively Figure (2).

Several investigators had higher results of S.aureus in the small scale yoghurt samples as Oksuztepe et al. (2007) and Abou El-Makarem (2013).

Nearly similar counts of S.aureus in the large scale yoghurt samples were postulated by Abdel-Fattah (2007), while higher values were observed by Abou El-Makarem (2013) and Ahmed et al. (2014), but lower results were obtained by El-Bessery (2001).

Similarly, the counts of S.aureus in the Tallaga cheese samples were previously found by Aiad (2013), however lower results were reported by Ghada et al. (2004) and Amer et al. (2005).

The dropping of S.aureus counts in the Feta cheese samples were detected by Al-Tahiri (2005) and El Sayed et al. (2011).
The lower rate of contamination in the small scale rayeb milk samples were observed by Shawer (2013) and Tarekgne et al. (2015), but in the large scale rayeb milk lower count were demonstrated by ElBessery (2001) and Shawer (2013).

In spite of pasteurization destroy S. aureus pathogen, thermostable SEs can resist heat treatment and still spirit with their biological activity which may cause severe health hazard (Balaban and Rasooly 2000). Also, the presence of less than $10^{6}$ staphylococcal counts in the products doesn't help in enterotoxin production (Tatini, 1973 and Robinson, 2002).

The obtained results in Figure (3) regarded that $60 \%$ of the examined $S$. aureus strains were enterotoxigenic by PCR technique as carried one or two se- genes and See gene consider the highest frequency incidence $3(60 \%)$ then Seb and Sec $1(20 \%$ of each) but the Sea and Sed could not be detected.

Higher values were recorded by Morandi et al. (2007) and Mathenge et al. (2015), but lower results were indicated by Arcuri et al. (2010) and Kav et al. (2011).

Probiotics are live organisms that produce benefits to health of the consumer or host when ingested through their ability to implantation on the intestinal microflora, resist gastric acidity and bile digestion (Sfakianakis and Tzia, 2014). Also, probiotics are added with concentrations of $10^{7}-10^{8} \mathrm{cfu} / \mathrm{gm}$ or $\mathrm{ml}$. as adjunct cultures to food and products, if no longer participating or participating in the fermentation, they able to reach a concentration of $10^{8}-10^{9} \mathrm{cfu} / \mathrm{g}$ or $\mathrm{ml}$ after the fermentation happened (Vinderola et al., 2011). 
The mechanism of lactic acid bacteria "LAB" in the controlling of microbial and pathogens growth is their production of lactic acid in addition to other antimicrobial compounds which exerted inhibition action on the growth of pathogens (Tadesse et al., 2005).

Lactobacillus acidophilus had antagonistic actions against Staphylococcus aureus as it secretes hydrogen peroxides which partially responsible for antimicrobial interaction rather than the produced amounts of acid (Gilliand and Speck, 1977).

The result obtained in Figure (4) showed that after 30 days refrigerator storage control Tallaga cheese had $\mathrm{pH}$ value "4.8", L.acidophilus Tallaga had "4.0" and B.bifidum Tallaga cheese "4.3".

From the data presented in Figure (5) it is evident that the salt content $(\mathrm{NaCl} \%)$ nearly similar in L.acidophilus Tallaga cheese, B.bifidum Tallaga cheese and control one during production and after 30 days refrigerator storage.

The results given in Figure (6) showed that L.acidophilus strain had inhibitory effect on S.aureus organism viability in Tallaga cheese as decreased its count from $6.7 \times 10^{8}$ to $9.0 \times 10^{3} \mathrm{cfu} / \mathrm{g}$ through a month storage in the refrigerator than control one that decreased from $6.7 \times 10^{8}$ to $3.0 \times 10^{7} \mathrm{cfu} / \mathrm{g}$ and the results were in harmony with the results obtained by Arques et al. (2005), Charlier et al. (2009) Amer (2011) and Abou ElMakarem (2013)., but did not agree with that postulated by Abd El-Gawad et al. (2014).

In Figure (7) it was found that B.bifidum strains had antimicrobial effect against S.aureus pathogen growth in Tallaga cheese as lowering its count from $6.8 \times 10^{8}$ to $1.6 \times 10^{4} \mathrm{cfu} / \mathrm{g}$ through a month storage in the refrigerator than control one that decreased from $6.7 \times 10^{8}$ to $3.0 \times 10^{7} \mathrm{cfu} / \mathrm{g}$ and this agree with Arques et al. (2005), Charlier et al. (2009) and Abou ElMakarem (2013) .

The antimicrobial properties of yoghurt samples were mostly higher than these of the cell free and these activities may due to lactic acid production, decreasing in $\mathrm{pH}$ and also other antimicrobial compound that may be present in the yoghurt (Hassan et al., 2013).

The data illustrated in Figure (8) showed that after 15 days refrigerator storage control rayeb milk had PH values "3.2", L.acidophilus "2.9" and B.bifidum rayeb milk "3.0" and these result agree with that revealed Abd El-Gawad et al. (2014).

It is evident from the results which presented in Figure (9) that L.acidophilus strains had antibacterial effect on S.aureus organism viability in the rayeb milk as lowered its count from $7.8 \times 10^{8}$ to $1.0 \times 10^{3} \mathrm{cfu} / \mathrm{ml}$ through 15 days storage in the refrigerator than control one that decreased from 8.0 $\mathrm{x} 10^{8}$ to $2.5 \times 10^{7} \mathrm{cfu} / \mathrm{ml}$ and these data was nearly similar to that obtained by Arques et al. (2005), Charlier et al. (2009), Kaboosi (2011) and Abou ElMakarem (2013), but did not agree with that revealed by Abd El-Gawad et al. (2014).

It is clear from the data showed in Figure (10) that B.bifidum strains had inhibitory effect against S.aureus growth in the rayeb milk as decreased its count from $7.7 \times 10^{8}$ to $2.1 \times 10^{3} \mathrm{cfu} / \mathrm{ml}$. through 15days storage in the refrigerator than control one that decreased from $8.0 \times 10^{8}$ to $2.5 \times 10^{7} \mathrm{cfu} / \mathrm{ml}$ and the results were nearly similar to those recorded by Arques et al. (2005), Charlier et al. (2009), Kaboosi (2011) and Abou El-Makarem (2013).

Finally, it is clear the importance of probiotics to health of the consumers when ingested in the dairy products and we advise that all dairy products must be produced with addition of probiotics at a certain number to produce a good quality and safe guard dairy product.

\section{CONCLUSION}

It was concluded from this work that some of dairy products as yoghurt, soft cheese and rayeb milk sold in Beni-Suef city, Egypt were of bad quality as heavy microbial contaminated with S.aureus that rendering them threating to public health and may causes many diseases .

Also, the information which given in this work demonstrated that for improvement the microbiological quality of dairy products probiotics strains as L.acidophilus and B.bifidum may be used as it's have antagonistic affect against many species like S.aureus strain so, these confirm the health benefits derived from the human consumption of fermented dairy products.

\section{REFERENCES}

A.P.H.A. "American Public Health Association" (1992): Standard Methods for the Examination of Dairy Product. $16^{\text {th }}$ ed., New York.

A.P.H.A. "American Public Health Association" (1974): Standard Methods for the Examination of Dairy Products. $13^{\text {th }}$. ed, New York:

Abd El-Gawad, I.A.; El-Sayed, E.M.; El- Zeini, H.M.; Hafez, S.A. and Saleh, F.A. (2014): Antibacterial activity of probiotic yoghurt and soy-yoghurt against escherichia coli and staphylococcus aureus. J. Nutr. Food Sci, 4: 1-6. 
Abdel-Fattah, E.N. (2007): Sanitary studies on fermented milks marketed at Zagazig markets. Ph. D. Thesis, Fac. Vet. Med., Zagazig University.

Abou El-Makarem, H.S.M. (2013): Biocontrol of some food borne pathogens isolated from traditional fermented milk. Ph.D. Thesis, Fac. Vet. Med., Alexandria University.

Abou-Donia, S.A. (1986): Egyptian domiati soft white pickled cheese. New Zealand J. Dairy Sci. Technol., 21.167-190.

Ahmed, L.I.; Morgan, S.D.; Hafez, R.S. and AbdelAll, A.A.A. (2014): Hygienic quality of some fermented milk products. Int. J. Dairy Sci., 9(8): 68-78.

Aiad, A.S. (2013): Microbial hazards assessment during white cheese production in a traditional dairy plant. Assiut Vet. Med. J., 59(137): 57-63.

Al-Tahiri, R. (2005): A comparison on microbial conditions between traditional dairy products sold in Karak and some products produced by modern dairies. Pakistan J. Nutr., 4 (5): 345348.

Álvarez-León. E.E.; Román-Viñas, B. and SerraMajem, L. (2006): Dairy products and health: a review of the epidemiological evidence. Brit. J. Nutr., 96: 94-99.

Amer, A.A. (2011): Probiotics as a tool to improve microbial quality of soft cheese. Assiut Vet. Med. J., 57(129): 44-57.

Amer, I.H.; Abd El-Aal, S.F. and Kamal, R.M. (2005): Comparative microbiological study on soft cheese manufactured by small or large scale production in Sharkia province, Egypt. Zagazig. Vet. J., 33(3):190-196.

Araujo, V.S.; Pagliares, V.A.; Queiroz M.L.P. and Freitas-Almeida, A.C. (2002): Occurrence of Staphylococcus and enteropathogens in soft cheese commercialized in the city of Rio de Janeiro, Brazil. J. Appl. Microbiol., 92: 1172-1177.

Arcuri, E.F.; Angelo, F.F.; Guimarães, M.F.; Talon, R.; Borges Mde, F.; Leroy, S.; Loiseau, G.; Lange, C.C.; Andrade, N.J. and Montet, D. (2010): Toxigenic status of Staphylococcus aureus isolated from bovine raw milk and Minas frescal cheese in Brazil. J. Food Prot., 73(12): 2225-2231.

Argudín, M.Á.; Mendoza, M.C. and Rodicio, M.R. (2010): Food poisoning and Staphylococcus aureus enterotoxins," Toxins, 2(7): 17511773.

Arques, J.L.; Rodri'guez, E.; Gaya, P.; M. Medina, M.; Guamis, B. and Nunez, M. (2005): Inactivation of Staphylococcus aureus in raw milk cheese by combinations of high-pressure treatments and bacteriocin producing lactic acid bacteria. J. Appl. Microbiol.,98: 254260.
Atichou, M.; Henkens, R.; Sultana, A.; Ulrich, R. and Ibrahim, M. (2004): Detection of Staphylococcus aureus enterotoxin A and B genes with PCR-EIA and a hand-held electrochemical sensor. Mol. Cell Probes., 18:373-377.

Balaban, N. and Rasooly, A. (2000): Staphylococcal enterotoxins. Int. J. Food Microbiol., 61: 110.

Bergamini, C.V.; Hynes, E.R.; Quiberoni, A.; Suarez, V.B. and Zalazar, C.A. (2005): Probiotic bacteria as adjunct starters: influence of the addition methodology on their survival in semi-hard Argentinean cheese. Int. Food Res., 38: 597-604.

Bergdoll, M.S. (1991): Staphylococcus aureus. J. Association of Official Analytical Chemists 74: 706-710.

Boerema, J.A.; Clemens, $R$. and Brightwell, G. (2006): Evaluation of molecular methods to determine enterotoxingenic status and molecular genotype of bovine, ovine, human and food isolates of Staphylococcus aureus. Int. J. Food Microbiol., 107: 192-201.

Chaibenjawong, P. and Foster, S.J. (2011): Desiccation tolerance in Staphylococcus aureus," Archives Microbiol., 193(2): 125135.

Charlier, C.; Cretenet, M.; Even, S. and Le Loir, Y. (2009): Interactions between Staphylococcus aureus and lactic acid bacteria: An old story with new perspectives. Int. J. Food Microb., 15th Meeting of the Club des Bacteries Lactique131: 30-39.

Chowdhury, A.; Md Hossain, N.; Mostazir, N.J.; Md Fakruddin. and Md Billah, M. (2012): Screening of Lactobacillus spp. from Buffalo Yoghurt for Probiotic and Antibacterial Activity. J. Bacteriol. Parasitol., 3: 156.

Cueva, O. and Aryana, K.J. (2008): Quality attributes of a heart healthy yogurt. LWT Food Sci. Technol., 41: 537-544.

El Sayed, M.A.; Hosny, I.M.; El Kholy, W.I.; El Dairouty, R.K. and Mohamed, S.H.S. (2011): Microbiological evaluation of Egyptian white soft cheeses style. American Sci. J., 7(5): 517-526.

El-Bessery, M.M.A. (2001): Microbiological quality of market fermented milks in Assiut city. M.V.sc Fac. Vet. Med., Assiut University.

FAO/WHO "Food and Agriculture Organization/ World Health Organization" (2001): Health and nutritional properties of probiotics in food including powder milk with live lactic acid bacteria. Cordoba, Argentina 1-4 October 2001.

Fooladi, I.A.A.; Tavakoli, H.R. and Naderi, A. (2010): Detection of enterotoxigenic Staphylococcus aureus isolates in domestic dairy products. Iran. J. Microbiol., 2 (3): 137142. 
Ghada, Z.A.A.; Alia, M.H.; Soha, Al-S.; Magdy, N.A. and Mohammed, F.S. (2004): Chemical, nutritional and microbiological evaluation of some Egyptian soft cheeses. The Egyptian J. Hospital Medicine, 17: 44-57.

Gibson, G.R. (2002): Intestinal microflora research for the 21st Century. Bioscience Microflora, 20(4): 131-134.

Gilliand, S.E. and Speck, M.L. (1977): Antagonistic action of Lactobacillus acidophilus towards intestinal and food borne pathogens in associative culture. J. Food Prot., 40: 820823.

Guarner, F.; Perdigon, G.; Corthier, G.; Salminen, S.; Koletzko, B. and Moralli, L. (2005): Should yoghurt cultures be considered probiotics? Brit. J. Nutr., 93: 783-786.

Hassan, A.M.; Abdallah, M.I.M.; Bazalou, M.S. and Abo-Samra, R.G. (2013): Effect of probiotics bacteria isolated from yoghurts produced in Damietta city on some pathogenic bacteria. Animal Wealth Research Conference in the Middle East and North Africa, Hurghada Information Center, pp. 38-51.

Hathout, A.S. and Aly, S.E. (2010): Role of lactic acid bacteria as a biopreservative agent of Talbina. J. American Sci., 6(12) 889-898.

Hoven, M. (1987): Functionality of dairy ingredients in meat products. Food Technol, 8: 72-78.

Huis In't Veld, J.H.J. and Short, C. (1996): Selection criteria for probiotic microorganisms. London: The Royal Society of Medicine Press Ltd, International Congress and Symposium Series, 219: 27-36.

Ishibashi, N. and Shimamura, S. (1993): Bifidobacteria: Research and development in Japan. J. Food Technol., 46: 126-135.

Jay. M.J.; Loessner, J.M. and Golden, A.D. (2005): Staphylococcal gastroenteritis. In: Modern Food Microbiology. $7^{\text {th }}$ ed. Springer Science, New York, pp: 545-560.

Kaboosi, H. (2011): Antibacterial effects of probiotics isolated from yoghurts against some common bacterial pathogens. Afri. J. Microbiol. Res., 5(25): 4363-4367.

Kav, K.; Col, R. and Ardic, M. (2011): Characterization of Staphylococcus aureus Isolates from White-Brined Urfa Cheese. J. Food Prot, 74(11): 1788-1796.

Kluytmans, J.A.J.W. and Wertheim, H.F.L. (2005): Nasal carriage of 5. Staphylococcus aureus and prevention of nosocomial infections. Infection, 33: 3-7.

Le Loir, Y.; Baron, F. and Gautier, M. (2003): Staphylococcus aureus and food poisoning. Genet Mol. Res., 2(1): 63-67.

Lee, Y.K. and Salminen, S. (1995): The coming of age of probiotics. Trends Food Sci Technol.,6: 241-5.

Letetre, C.; Perelle, S.; Dilasser, F. and Fach, P. (2003): Identification of a new putative enterotoxin SEU encoded by the egc cluster of Staphylococcus aureus. J. Appl. Microbiol., 95: 38-43.

Loncarevic, S.; Jørgensen, H.J.; Løvseth, A.; Mathisen, T. and Rorvik, L.M. (2005): Diversity of Staphylococcus aureus enterotoxin types within single samples of raw milk and raw milk products. J. Appl. Microbiol., 98: 344-350.

Mathenge, J.M.; Okemo, P.O.; Nganga, P.M.; Mbaria, J.M. and Gicheru, M.M. (2015): Identification of enterotoxigenic Staphylococcus aureus strains from meat and dairy products by multiplex PCR and reverse passive latex agglutination test in Nairobi, Kenya. East and Central Africa Medical J., 2: 97-103.

McKinley, M.C. (2005): The nutrition and health benefits of yoghurt. Int. J. Dairy Technol., 58: $1-12$.

Mclauchlin, J.; Narayanan, G.L.; Mithani, V. and O'neill, G. (2000): The detection of enterotoxins an toxin shock syndrome toxin genes in Staphylococcus aureus by polymerase chain reaction. J. Food Prot., 63:.479- 488

Mehrotra, M.; Wang, G. and Johnson, M. (2000): Multiplex PCR for detection of genes for Staphylococcus aureus enterotoxins, exfoliative toxins, toxic shock syndrome toxin 1, and methicilin resistance. J. Clin. Microbiol, 38(3):1032-1035.

Mercenier, A.; Pavan, S. and Pot, B. (2003): Probiotic as biotheraputic agents present knowledge and futures prospects. Current Pharmaceutical Design, 8:99-101.

Millette, M.; Luquet, F.M. and Lacroix, M. (2007): In vitro growth control of selected pathogens by Lactobacillus acidophilus and Lactobacillus Casei-fermented milk. Lett. Appl. Microbiol., 44(3), 314-319.

Mohamed, B.J.; AL-Hussain, R.A. and AL. Thwani, A.N. (2010): Study the in inhibitory effect of Lactobacillus acidophilus isolated from yoghurt as probiotics on candida albicans growth in vitro and in vivo. Iraqi J. Biotech., 9(2): 167-179.

Morandi, S.; Brasca, M.; Andrighetto, C.; Lombardi, A. and Lodi, R. (2009): Phenotypic and genotypic characterization of Staphylococcus aureus strains from Italian dairy products. Int. J. Microbiol.; 1-7.

Morandi, S.; Brasca, M.; Lodi, R.; Cremonesi, P. and Castiglioni, B. (2007): Detection of classical enterotoxins and identification of enterotoxin genes in Staphylococcus aureus from milk and dairy products. J. Vet. Microbiol., 124: 66-72.

Najera-Sanchez, G.; Maldonado-Rodri'Guez, R.; Rui'Z Olvera, P. and De La Garza, L.M. (2003): Development of two multiplex 
polymerase chain reactions for the detection of enterotoxigenic strains of Staphylococcus aureus isolated from foods. J. Food. Prot., 66(6): 1055-1062.

Oksuztepe, G.A.; Patir, B.; Dikici, A.; Bozkurt, O.P. and Çalicioğlu, M. (2007): microbiological and chemical quality of cokelek marketed in Elazı̆̆. F.Ü. Sağ. Bil. Derg., 21 (1): 27 - 31.

Omoe, K.; Machiko, I.; Shimoda, Y.; Dong-Liang, H. and Ueda, S. (2002): Detection of seg, she and sei genes in Staphylococcus aureus isolates and determination of the enterotoxin productivities of $\mathrm{S}$. aureus isolates harboring seg, she or sei genes. J. Clin. Microbiol., 40: 857-862.

Paciorek, M.L.; Kochman, M.; Piekarska, K.; Grochowska, A. and Windyg, B. (2007): The distribution of enterotoxin and enterotoxinlike genes in Staphylococcus aureus strains isolated from nasal carriers and food samples. Int. J. Food Microbiol., 117: 319-323.

Pal, M. and Jadhav, V.J. (2013): Significance of probiotics in human health. Beverage and Food World, 40: 65-67.

Pesavento, G.; Ducci, B.; Comodo, N. and Nostro, A.L. (2007): Antimicrobial resistance profile of Staphylococcus aureus isolated from raw meat: A research for methicillin resistant Staphylococcus aureus (MRSA). Food Control, 18: 196-200.

Prasad, J.; Gill, H.; Smart, J. and Gopal, P.K. (2000): Selection and Characterisation of Lactobacillus and Bifidobacterium strains for use as probiotics. Int. Dairy J., 8: 993-1002

Quinn, P.J.; Markey, B.K.; Carter, M.E.; Donnelly, W.J.C.; Leonard, F.C. and Maguire, D. (2002): Veterinary Microbiology and Microbial Diseases.1st published Blackwell Science ltd.

Quwehand, A.C. and Vesterlund, S. (2004): Antimicrobial components from lactic acid bacteria. Lactic Acid Bacteria Microbiological and Functional Aspects, Marcel Dekker Inc., New York, USA.

Ramesh, C.C. and Arun, K. (2013): Manufacturing Yogurt and Fermented Milks. John Wiley \& Sons.

Roberts, D. and Greenwood, M. (2003): Practical Food Microbiology, $3^{\text {rd }}$ ed., Blackwell Publishing Ltd, Oxford, UK.

Robinson, R.K. and Tamime, A.Y. (2002): Maintaining a clean working environment. In: Robinson, R.K. (Ed.), Dairy Microbiology Handbook, the Microbiology of Milk and Milk Products, $3^{\text {rd }}$ ed. Wiley, New York, pp: 561-591.

Robinson, R.K. (2002): Dairy microbiology hand book. $3^{\text {rd }}$ Edition.

Robles Alonso, V. and Guarner, F. (2013): Linking the gut microbiota to human health. Br. J. Nutr., 109(Suppl 2): S21-6.
Salminen, S.; Bouley, C. and Boutron-Ruault, M.C. (1998): Functional food science and gastrointestinal physiology and function. $\mathrm{Br}$. J. Nutr., 80(suppl): S147-71.

Sanders, M.E. (2003): Probiotics: considerations for human health. Nutr. Rev.,61: 91-99.

Sayed, M. (2012): laban rayeb and yoghurt: sensory ‘ rheological, chemical and microbiological properties. Assiut Vet. Med. J. 58 (132): 126.

Sfakianakis, P. and Tzia, C. (2014): Conventional and innovative processing of milk for yogurt manufacture; development of texture and flavor: A Review. Foods 3: 176-193.

Sharma, N.K.; Rees, C.E. and Dodd, C.E. (2000): Development of a single-reaction multiplex pcr toxin typing assay for Staphylococcus aureus strains. J. Appl. Environ. Microbiol., 66(4): 1347-1353.

Shawer, H.I.A. (2013): Quality Assurance of Some Fermented Dairy Products Sold In Local Markets. Ph.D. Thesis, Fac. Vet. Med., Alexandria University.

Shijia, W.U.; Duan, N.; Huajie, G.U.; Hao, L.; Ye, H.; I Gong, W. and Wang, Z. (2016): A Review of the Methods for Detection of Staphylococcus aureus Enterotoxins. Toxins, 8(176):1-20

Souza, C.H.B. and Saad, S.M.I. (2009): Viability of Lactobacillus acidophilus La-5 added solely or in co-culture with a yoghurt starter culture and implications on physico-chemical and related properties of Minas fresh cheese during storage. Food Sci. Technol., 42 (2): 633-640.

Steinkraus, K.H. (1997): Classification of fermented foods: worldwide review of household fermentation techniques. Food Control, 8: 311-317.

Tadesse, G.; Ephraim, E. and Asheraiafi, M. (2005): Assessment of the antimicrobial activity of lavtic acid bacteria isolated from borde and shamita, traditionally Ethiopian fermented beverages, on some food borne pathogens and effect of growth medium on the inhibitory activity. Int. J. Food Safety, 5:1320.

Tamine, A.Y. (2002): Fermented milks: a historical food with modern applications - a review. Eur. J. Clin. Nutr., 56: 1-15.

Tamine, A.Y. and Robinson, R.K. (2007): Yoghurt: Science and Technology. $3^{\text {rd }}$ Ed. Cambridge, Woodhead Publishing Limited p: 808.

Tarekgne, E.; Skeie, S.; Rudi, K.; Skjerdal, T. and Narvhus, J.A. (2015): Staphylococcus aureus and other Staphylococcus species in milk and milk products from Tigray region, Northern Ethiopia. Afr. J. Food Sci., 9(12): 567-576.

Tatini S.R. (1973): Influence of food environment on growth of Staphylococcus aureus and 
production of various enterotoxins. J. Milk Technol., 36(11):559-563.

Un Lee, S.; Quesnell, M.; Fox, L.K.; Won Yoon, J.; Ho Park, Y.; Davis, W.C.; Falk, D.; Deobald, C.F. and Bohach, G.A. (1998): Characterization of staphylococcal bovine mastitis isolates using the polymerase chain reaction. J. Food Prot., 61: 1384-1386.

Vernozy-Rozand, C.; Mazuy-Cruchaudet, C.; Bavai, C. and Richard, Y. (2004): Comparison of three immunological methods for detecting staphylococcal enterotoxins from food. Lett. Appl. Microbiol., 39: 490-494.

Vinderola, G.; Binetti, A.; Burns, P. and Reinheimer, J. (2011): Cell viability and functionality of probiotic bacteria in dairy products. Front. Microbiol.; 2: 70

Yang, Z. (2000): Antimicrobial compounds and extracellular polysaccharides produced by lactic acid bacteria: structures and properties. Department of Food Technology, University of Helsinki.

Zschock, M.; Barbel Kloppert, W.W.; Hamman, H.P. and Lammler, Ch. (2005): Pattern of enterotoxin genes seg, seh, sei and sej positive Staphylococcus aureus isolated from bovine mastitis. J. Vet. Microbiol., 108: 243249.

\section{تأثير المعززات الحيوية على نمو المكور العنقودى الذهبى فى بعض المنتجات اللبنية

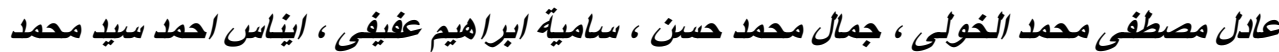

E-mail: bataahmed_2011@yahoo.com Assiut University web-site: www.aun.edu.eg

$$
\text { من فتبر الألبان ومنتجاتها من أكثر الأغذية أهمية وذلك لما تحتويه من العناصر الغذائية الضرورية لبناء جسم الإنسان ووقايتة من كثير }
$$

الجزء الاول: قد انتمل على جمع •11 عينة من الزبادي (صغير وكبير الانتاج) و الجبن الطري (تلاجة وفيتا) و اللبن الرايب (صغير

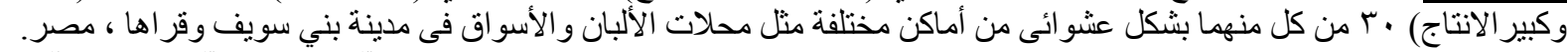

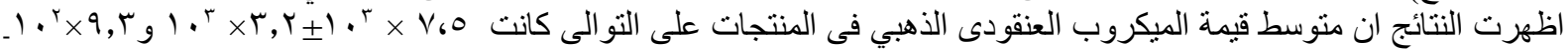

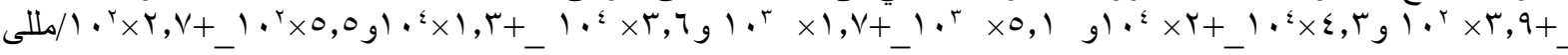

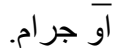

كذلك ، بينت النتائج بان ـ ـ ٪ من سلالات المكورات العنقودية الذهبية التى نم فحصهاعن طريق تقنبة انزيم البلمرة حملت واحد أو اثثين من جينات السموم المعوية.

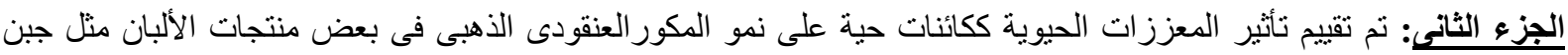

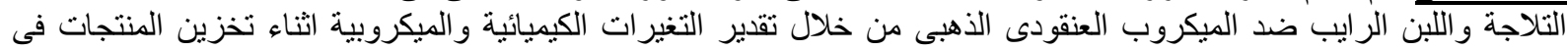

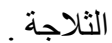

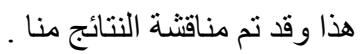

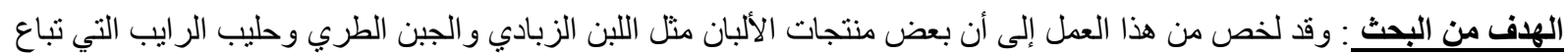

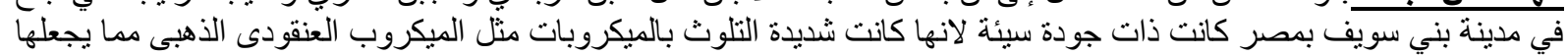

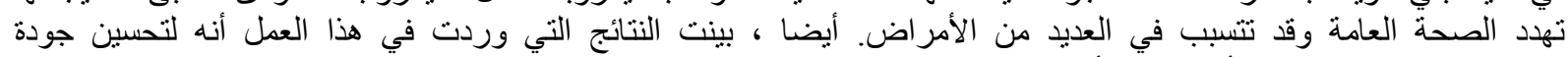

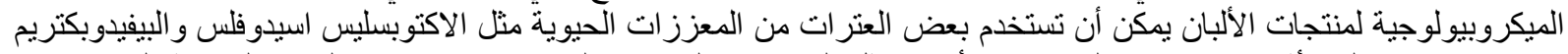

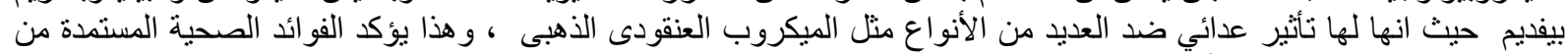

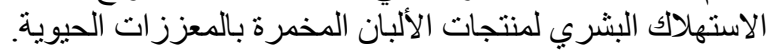

